\title{
Profil Pembelajaran Matematika pada Anak Berkebutuhan Khusus Ragam Slow Learner di Kelas Inklusif SMP Garuda Cendekia Jakarta
}

\author{
Heni Yunilda ${ }^{1 *}$, Syamsuri ${ }^{2}$, Cecep Anwar Hadi Firdos Santosa ${ }^{3}$, \\ Aan Subhan Pamungkas ${ }^{4}$ \\ 1,2,3,4 Universitas Sultan Ageng Tirtayasa \\ *heni.hasibuan@gmail.com
}

Diterima: Oktober 2019. Disetujui: Desember 2019. Dipublikasikan: Januari 2020

\begin{abstract}
ABSTRAK
Tujuan penelitian ini adalah untuk mengetahui profil pembelajaran matematika pada anak berkebutuhan khusus ragam lamban belajar atau lebih dikenal sebagai slow learner. Penelitian ini menggunakan pendekatan kualitatif metode studi kasus. Subjek penelitian ini adalah salah satu siswa slow learner di kelas inklusif SMP Garuda Cendekia Jakarta. Teknik pengumpulan data penelitian ini menggunakan metode wawancara semi-terstruktur. Validitas data dilakukan dengan menggunakan teknik triangulasi sumber. Teknik analisis data dilakukan melalui jalur reduksi data, penyajian data, serta penarikan kesimpulan dan verifikasi. Berdasarkan analisis data diperoleh hasil: (1) kurikulum yang digunakan slow learner disamakan dengan kurikulum reguler, tetapi dilakukan adaptasi kurikulum berupa modifikasi, (2) penggunaan model maupun metode pembelajaran di kelas inklusif disamakan antara slow learner dengan siswa reguler tanpa penyusunan program pembelajaran individual, tetapi pelaksanaannya dilakukan dengan memperhatikan karakteristik slow learner, dan (3) kegiatan evaluasi dilakukan melalui tes tertulis yang disusun oleh guru mata pelajaran yang kemudian dilakukan penyesuaian oleh guru pembimbing khusus berdasarkan model modifikasi.
\end{abstract}

Kata kunci: pembelajaran matematika, anak berkebutuhan khusus, slow learner, inklusif, modifikasi.

\begin{abstract}
This study aimed for unveiling mathematics-learning process of different abilities students in slow learning spectrum. This study used a qualitative approach by case study method. The subject of this research was one of SMP Garuda Cendekia's students with slow learning spectrum. The data were collected through the method of semi-structured interviews. The data was validated by using data triangulation technique. The data then was analyzed through flows of activity: data reduction, data display, and conclusion drawing/verification. The results were: (1) The curriculum used by the teacher for the research subject was the general curriculum, modified to cater the needs of the subject research, (2) the learning model and method for the subject research did not differ from the other students and was applied by considering the research subject's characteristic without the need of planning an individualized education program, and (3) written test was used as means of evaluation that was arranged by the mathematics subject teacher after being accommodated by the special education teachers based on the modified model.
\end{abstract}

Keywords: mathematics learning, different abilities, slow learner, inclusive, modifications.

How to Cite: Yunilda, H., Syamsuri, Santosa, C. A. H. F., \& Pamungkas, A. S. (2020). Profil Pembelajaran Matematika pada Anak Berkebutuhan Khusus Ragam Slow Learner di Kelas Inklusif SMP Garuda Cendekia Jakarta. Journal of Medives: Journal of Mathematics Education IKIP Veteran Semarang, 4(1), 37-51. 


\section{PENDAHULUAN}

Pendidikan memampukan manusia untuk berproses menuju kemandirian sehingga dapat berkontribusi terhadap masyarakat dan bangsanya (Fajarini, 2014). Oleh karena itu, sudah selayaknya pendidikan menjadi kebutuhan primer bagi setiap manusia yang harus dipenuhi. Begitu pula dengan pendidikan bermutu yang semestinya diperoleh tanpa memandang keterbatasan atau keluarbiasaan yang dimiliki oleh seseorang. Hal ini tercantum pada Pasal 5 Undang-Undang Republik Indonesia Nomor 20 Tahun 2003 tentang Sistem Pendidikan Nasional yang menyatakan bahwa setiap warga negara mempunyai hak yang sama untuk memperoleh pendidikan bermutu, tidak terkecuali bagi warga negara yang memiliki kelainan fisik, emosional, mental, intelektual, dan/atau sosial, serta yang memiliki potensi kecerdasan dan bakat istimewa. Kesamaan hak dalam memperoleh pendidikan bermutu antara anak yang memiliki keterbatasan atau keluarbiasaan dengan anak lainnya tersebut menjadi dasar terbentuknya sistem pendidikan inklusif yang menggabungkan penyelenggaraan pendidikan khusus dengan pendidikan reguler dalam satuan pendidikan yang sama (Wahyudi \& Kristiawati, 2016). Pendidikan inklusif memfasilitasi anak yang memiliki keterbatasan atau keluarbiasaan, biasa dikenal dengan Anak Berkebutuhan Khusus (ABK), untuk menjalani pembelajaran yang sama dengan anak reguler melalui pengakomodasian, disesuaikan dengan kebutuhan berdasarkan karakteristik ABK tersebut (Verbeke, 2002).
Anak berkebutuhan khusus disebutkan dalam Peraturan Menteri Negara Pemberdayaan Perempuan dan Perlindungan Anak Republik Indonesia Nomor 10 Tahun 2011 tentang Kebijakan Penanganan Anak Berkebutuhan Khusus yang tercantum pada Pasal 1 mempunyai definisi sebagai anak yang mengalami keterbatasan atau keluarbiasaan baik fisik, mentalintelektual, sosial, maupun emosional yang berpengaruh secara signifikan dalam proses pertumbuhan dan perkembangannya dibandingkan dengan anak-anak lain seusianya. Senada dengan definisi tersebut, Kementerian Pendidikan dan Kebudayaan pun mengeluarkan peraturan yang membahas tentang siswa berkelainan, seperti tercantum pada Peraturan Menteri Pendidikan dan Kebudayaan Republik Indonesia Nomor 157 Tahun 2014 Pasal 1 tentang Kurikulum Pendidikan Khusus yang menyatakan bahwa siswa berkelainan adalah siswa berkebutuhan khusus yang memiliki kesulitan dalam mengikuti proses pembelajaran karena kelainan fisik, emosional, mental, intelektual, dan/atau sosial. Ragam siswa berkebutuhan khusus pun lebih jelas lagi dinyatakan dalam Pasal 4, yaitu tunanetra, tunarungu, tunawicara, tunagrahita, tunadaksa, tunalaras, berkesulitan belajar, lamban belajar, autis, memiliki gangguan motorik, menjadi korban penyalahgunaan narkoba, memiliki kelainan lain, ataupun tunaganda.

Anak berkebutuhan khusus ragam lamban belajar atau lebih dikenal sebagai slow learner didefinisikan oleh Kementerian Pemberdayaan Perempuan dan Perlindungan Anak Republik Indonesia 
yang tercantum pada Peraturan Menteri Negara Pemberdayaan Perempuan dan Perlindungan Anak Republik Indonesia Nomor 10 Tahun 2011 tentang Kebijakan Penanganan Anak Berkebutuhan Khusus sebagai anak yang memiliki potensi intelektual sedikit di bawah rata-rata tetapi belum termasuk gangguan mental. Lebih spesifik slow learner diidentifikasikan sebagai anak yang memiliki IQ dengan rentang 70 85 (Kaznowski, 2004) atau pada rentang 75 - 89 (Malik, Rehman, \& Hanif, 2012) sehingga secara umum potensi intelektual slow learner ada pada rentang 70 90 (Krishnakumar et al., 2011). Slow learner mempunyai tingkat perhatian dan daya konsentrasi yang rendah terhadap informasi yang disampaikan (Aziz, Sugiman, \& Prabowo, 2015; Pandey \& Kurian, 2016; Yusuf et al., 2018). Hal ini menjadikan slow learner mempunyai daya ingat yang rendah karena kekurangmampuan mereka untuk merekam informasi dalam jangka panjang (Tran et al., 2019; Yusuf et al., 2018).

Beberapa penelitian menyatakan bahwa slow learner memiliki kesulitan dalam pembelajaran yang berkaitan dengan membaca, menulis, dan matematika (Kaznowski, 2004; Krishnakumar et al., 2011; Levine \& Barringer, 2008; Tran et al., 2019). Slow learner juga membutuhkan waktu yang lebih lama dalam memahami suatu materi akademik dan membutuhkan penjelasan yang dilakukan secara berulang (Aziz et al., 2015; Shaw, 2010; Yusuf et al., 2018). Keterbatasan belajar ini menjadikan slow learner mengalami hambatan dalam belajar sehingga slow learner pada umumnya memiliki prestasi belajar yang lebih rendah daripada siswa reguler (Shaw, 2008; Watson \& Rangel, 1989; Winarsih et al., 2013; Yusuf et al., 2018).

Slow learner secara fisik akan sulit untuk diidentifikasi karena penampilan fisik mereka pada umumnya sama dengan siswa reguler dan tidak menunjukkan perbedaan fungsi (Yusuf et al., 2018). Penampilan luar yang dapat diidentifikasi dari slow learner adalah pada saat mereka berkomunikasi dengan orang lain. Slow learner menunjukkan respon yang lebih lambat saat berbicara (Yusuf et al., 2018) sehingga slow learner juga dapat diidentifikasikan sebagai anak yang memiliki kesulitan dalam berkomunikasi (Tran et al., 2019). Hal ini menjadikan slow learner mempunyai kesulitan dalam menyampaikan ide yang muncul dari dirinya (Shaw, 2010; Tran et al., 2019). Meskipun begitu, slow learner pada umumnya tidak memiliki kesulitan dalam bersosialisasi dengan orang lain dan juga ketika berinteraksi pada grup belajar (Kaznowski, 2004; Watson \& Rangel, 1989).

Slow learner sebagai salah satu ragam anak berkebutuhan khusus tentunya mempunyai hak untuk menempuh pendidikan di sekolah umum yang menerapkan pembelajaran dengan sistem pendidikan inklusif. Hal ini tentu saja berimplikasi kepada kesamaan materi pembelajaran yang diperoleh antara slow learner dengan siswa reguler, tak terkecuali pembelajaran matematika. Meskipun demikian, sekolah yang menerapkan pendidikan inklusif melakukan adaptasi kurikulum dengan 
melakukan penyesuaian materi pembelajaran terhadap karakteristik siswa berkebutuhan khusus (Yusuf et al., 2018). Karakteristik slow learner yang memiliki kesulitan dan hambatan dalam memahami materi matematika (Hadi, 2016; Shaw, 2008), kemampuan abstraksi yang rendah (Tran et al., 2019), kesulitan dalam menggeneralisasikan konsep pada saat menyelesaikan masalah matematika (Shaw, 2010), serta berbagai karakteristik lainnya yang berbeda dari siswa reguler menjadikan slow learner memerlukan usaha yang lebih daripada anak reguler sebayanya dalam memahami materi matematika.

Usaha yang dilakukan siswa slow learner dalam memahami materi matematika tentunya tidak lepas dari keterlibatannya dalam proses pembelajaran matematika di kelas reguler. "Proses pembelajaran matematika ini melibatkan pengetahuan dari beragam domain, seperti pengetahuan tentang bidang studi yang akan diajarkan, perbedaan siswa, cara siswa belajar, lingkungan kelas, lembaga pendidikan, dan masyarakat" (Rohaeti et al. 2019:2). Penggabungan pembelajaran matematika slow learner dengan siswa reguler dalam kelas yang sama tentunya memerlukan perencanaan, pelaksanaan, dan evaluasi yang disesuaikan dengan prinsip pendidikan inklusif, yaitu pembelajaran yang memfasilitasi kebutuhan slow learner, disesuaikan dengan karakteristik slow learner.

Oleh karena itu, perlu dilakukan penelitian yang mampu mengungkap proses pembelajaran matematika pada anak berkebutuhan khusus ragam slow learner di kelas inklusif, mulai dari perencanaan, pelaksanaan, dan evaluasi pembelajaran. Hasil penelitian ini nantinya akan memberikan informasi dan pengetahuan terhadap domain perbedaan siswa reguler dengan siswa slow learner, cara belajar siswa slow learner, lingkungan kelas inklusif antara siswa reguler dengan siswa slow learner, serta satuan pendidikan yang menyelenggarakan sistem pendidikan inklusif. Hasil penelitian ini juga nantinya akan memberikan gambaran sejauh mana keterlibatan guru pembimbing khusus dalam proses pembelajaran matematika siswa slow learner di kelas inklusif.

\section{METODE PENELITIAN}

Penelitian ini menggunakan pendekatan kualitatif yang bermaksud untuk mengungkapkan, menggambarkan, dan mendeskripsikan proses pembelajaran matematika pada siswa berkebutuhan khusus ragam slow learner di kelas inklusif. Metode yang digunakan dalam penelitian ini adalah studi kasus dengan memahami proses pembelajaran matematika pada seorang siswa berkebutuhan khusus ragam slow learner secara lebih mendalam melalui pengumpulan data dari berbagai sumber informasi (Raco, 2010). Penelitian dilakukan pada bulan September-Oktober 2019 di salah satu sekolah inklusif di Jakarta, yaitu SMP Garuda Cendekia.

Teknik pengumpulan data penelitian menggunakan metode wawancara semi-terstruktur dengan berpandu pada pedoman pertanyaan (Agusta, 2003) yang kemudian disesuaikan dengan jawaban interviewee (orang yang diwawancara) dan situasi pada saat wawancara (Edi, 2016). Metode ini 
digunakan untuk mengungkap dan menggali informasi secara lebih luas dalam memahami proses pembelajaran matematika pada siswa slow learner di kelas inklusif (Edi, 2016; Qu \& Dumay, 2011). Peneliti berlaku sebagai interviewer dan yang menjadi interviewee adalah kepala SMP Garuda Cendekia (memiliki latar belakang pendidikan luar biasa), guru mata pelajaran matematika (memiliki latar belakang bidang pendidikan matematika), guru pembimbing khusus I (memiliki latar belakang pendidikan luar biasa), dan guru pembimbing khusus II (memiliki latar belakang pendidikan matematika). Pertanyaan yang diajukan adalah mengenai proses pembelajaran matematika pada siswa slow learner di kelas inklusif, mulai dari perencanaan, pelaksanaan, dan evaluasi pembelajaran serta keterlibatan guru pembimbing khusus dalam proses pembelajaran.

Validitas data dilakukan dengan menggunakan teknik triangulasi sumber, yaitu melalui pengecekan ulang terhadap derajat kepercayaan informasi melalui sumber yang berbeda (Bachri, 2010) sehingga dapat mengurangi subjektifitas dalam menginterpretasi data karena dilakukan dengan satu metode saja (Jonsen \& Jehn, 2009). Sumber yang dimaksud adalah empat orang interviewee yang memiliki keterikatan satu sama lain terhadap pelaksanaan pembelajaran matematika siswa slow learner di kelas inklusif SMP Garuda Cendekia Jakarta. Teknik triangulasi yang dilakukan pada penelitian ini dapat digambarkan seperti pada Gambar 1. Teknik analisis data yang digunakan meliputi: (1) reduksi data; (2) penyajian data; serta (3) penarikan kesimpulan dan verifikasi (Miles \& Huberman, 1994).

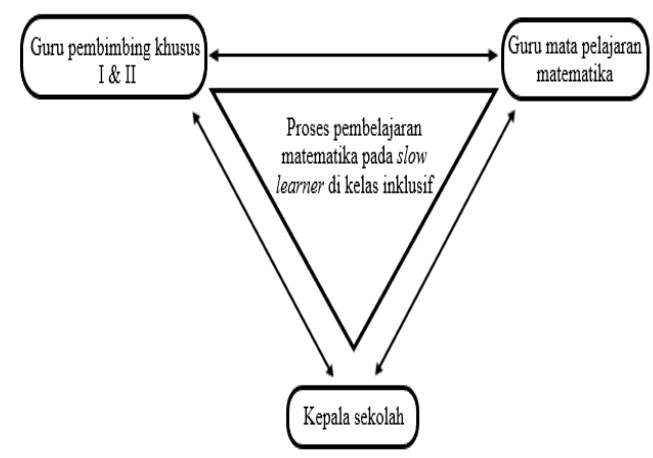

Gambar 1. Teknik Triangulasi Sumber

\section{HASIL DAN PEMBAHASAN}

SMP Garuda Cendekia merupakan salah satu sekolah di Jakarta yang menerapkan sistem pendidikan inklusif dengan memfasilitasi siswa berkebutuhan khusus untuk memperoleh pendidikan yang layak dan bermutu di sekolah reguler (Wahyudi \& Kristiawati, 2016) sejak tahun 2011. Siswa berkebutuhan khusus ditempatkan dalam ruang kelas yang sama dengan siswa reguler sehingga tidak ada perbedaan lingkungan belajar antara keduanya (Handayani \& Rahadian, 2013). Setiap rombongan belajar di SMP Garuda Cendekia merupakan kelas inklusif dengan menempatkan siswa berkebutuhan khusus maksimal tiga orang.

Namun demikian, karena keterbatasan jumlah guru pembimbing khusus, SMP Garuda Cendekia mempunyai kebijakan dalam hal penerimaan ragam siswa berkebutuhan khusus. Ragam siswa berkebutuhan khusus yang diterima di sekolah ini adalah slow learner, gifted, autisme, tuna daksa, tuna rungu, siswa berkesulitan belajar seperti disleksia, diskalkulia, serta siswa dengan 
hambatan emosi perilaku seperti bipolar, attention deficit disorder (ADD), maupun attention deficit hyperactive disorder (ADHD). Ragam ini ditunjukkan dalam rekam medis hasil pemeriksaan psikologis siswa berkebutuhan khusus sebelum menempuh pendidikan di SMP Garuda Cendekia. Hal tersebut dimaksudkan agar pihak sekolah tidak lagi menerka-nerka ragam siswa berkebutuhan khusus sehingga nantinya dapat memberikan fasilitas yang tepat sesuai dengan karakteristik dan kebutuhan siswa berkebutuhan khusus tersebut.

Penggabungan siswa berkebutuhan khusus dengan siswa reguler dalam ruang kelas belajar yang sama tentunya membutuhkan pendampingan dari guru pembimbing khusus dalam pelaksanaan proses pembelajaran di kelas (Wahyudi \& Kristiawati, 2016; Yusuf et al., 2018). Oleh karena itu, SMP Garuda Cendekia menyediakan guru pembimbing khusus untuk mendampingi dan memberikan bantuan kepada guru mata pelajaran dalam melaksanakan pembelajaran di kelas inklusif. Guru pembimbing khusus di sekolah ini berjumlah 7 orang yang berperan dalam mendampingi siswa berkebutuhan khusus sebanyak 24 orang. Hal ini sesuai dengan Peraturan Menteri Pendidikan Nasional Republik Indonesia Nomor 70 Tahun 2009 tentang Pendidikan Inklusif bagi Peserta Didik yang Memiliki Kelainan dan Memiliki Potensi Kecerdasan dan/atau Bakat Istimewa pada Pasal 10 yang menyatakan bahwa setiap satuan pendidikan penyelenggara pendidikan inklusif wajib menyediakan minimal satu orang guru pembimbing khusus.
Setiap guru pembimbing khusus tersebut berperan dalam pendampingan siswa berkebutuhan khusus pada pembelajaran mata pelajaran tertentu sehingga masing-masing guru pembimbing khusus hanya fokus ke salah satu mata pelajaran saja. Mata pelajaran yang dilakukan pendampingan terhadap siswa berkebutuhan khusus adalah matematika, IPA, IPS, bahasa Indonesia, dan bahasa Inggris. Namun, banyaknya jumlah jam pelajaran pada mata pelajaran matematika untuk semua rombongan belajar menjadikan pembelajaran matematika membutuhkan dua orang guru pembimbing khusus dalam mendampingi semua siswa berkebutuhan khusus di kelas inklusif sekolah tersebut, termasuk siswa slow learner yang menjadi subjek penelitian.

Guru pembimbing khusus dalam pembelajaran matematika diampu oleh guru yang memiliki latar belakang pendidikan luar biasa dan latar belakang pendidikan matematika yang telah mendapatkan pelatihan pendidikan khusus/luar biasa (Handayani \& Rahadian, 2013). Hal ini sesuai dengan Pedoman Khusus Penyelenggaraan Pendidikan Inklusif tentang Pengadaan dan Pembinaan Tenaga Pendidik yang dipublikasikan oleh Direktorat Pembinaan Sekolah Luar Biasa Tahun 2007 dan Peraturan Menteri Pendidikan dan Kebudayaan Republik Indonesia Nomor 157 Tahun 2014 tentang Kurikulum Pendidikan Khusus pada Pasal 14 yang menyatakan bahwa satuan pendidikan penyelenggara pendidikan inklusif disyaratkan untuk menyediakan dan/atau menempatkan guru pembimbing khusus yang memiliki latar belakang pendidikan khusus/luar 
biasa atau yang pernah mendapatkan pelatihan tentang pendidikan khusus/luar biasa.

\section{Bagan Pembelajaran Matematika Slow Learner di Kelas Inklusif SMP Garuda Cendekia}

Proses pembelajaran matematika siswa slow learner di kelas inklusif SMP Garuda Cendekia dapat dilihat pada Gambar 2.

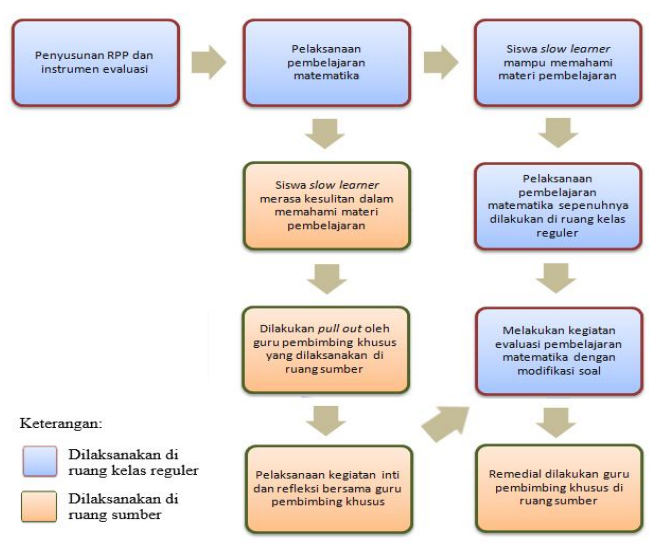

Gambar 2. Bagan Pembelajaran Matematika Slow Learner di Kelas Inklusif SMP Garuda Cendekia

\section{Perencanaan Pembelajaran Matema-} tika Slow Learner di Kelas Inklusif

Perencanaan pembelajaran di kelas inklusif SMP Garuda Cendekia disusun dalam bentuk rencana pelaksanaan pembelajaran yang disesuaikan dengan standar kurikulum 2013-revisi. Rencana pelaksanaan pembelajaran tersebut disusun oleh guru mata pelajaran yang mengampu setiap rombongan belajar dan ditujukan untuk semua siswa, baik siswa reguler maupun siswa berkebutuhan khusus dengan memperhatikan karakteristik dan kebutuhan dari masingmasing siswa berkebutuhan khusus. Dalam hal penyesuaian bagi siswa berkebutuhan khusus, SMP Garuda Cendekia juga menyusun program yang bersifat individual, disesuaikan dengan kemampuan siswa berkebutuhan khusus tertentu yang disebut sebagai program pembelajaran individual (Yusuf et al., 2018).

Namun demikian, pada siswa berkebutuhan khusus ragam slow learner di SMP Garuda Cendekia tidak terdapat perbedaan rencana pelaksanaan pembelajaran bagi siswa reguler dengan siswa slow learner. Guru pembimbing khusus juga tidak melakukan penyusunan program pembelajaran individual terhadap siswa slow learner. Kondisi tersebut didasari oleh pertimbangan pihak sekolah yang menganggap siswa slow learner masih mampu mengikuti materi kurikulum siswa reguler meskipun harus dilakukan adaptasi kurikulum dengan melakukan penyesuaian terhadap karakteristik siswa slow learner tersebut. Perlakuan tersebut dilakukan berdasarkan hasil rekam medis pemeriksaan psikologis siswa berkebutuhan khusus dan juga berdasarkan hasil observasi guru pembimbing khusus terhadap siswa slow learner di setiap awal tahun ajaran. Hal ini sesuai dengan hasil penelitian yang dilakukan oleh Febriyanti \& Irawan (2018) yang menyatakan bahwa materi yang akan dipelajari oleh siswa berkebutuhan khusus disesuaikan dengan kemampuan awalnya.

Rencana pembelajaran matematika pada siswa berkebutuhan khusus ragam slow learner di kelas inklusif dirancang oleh guru mata pelajaran matematika, dalam hal ini guru yang mengampu di kelas subjek penelitian, yaitu kelas VIIISudirman. Dalam perencanaan pembela- 
jaran matematika di kelas inklusif tersebut, guru mata pelajaran matematika memilih dan menentukan pendekatan, model, metode, dan strategi pembelajaran yang ditujukan untuk semua siswa, baik siswa reguler maupun siswa slow learner. Begitu juga dengan pemilihan media pembelajaran serta sumber belajar utama berupa buku teks materi pelajaran yang digunakan juga tidak terdapat perbedaan antara siswa reguler dengan siswa slow learner.

Pada tahap perencanaan pembelajaran ini, guru pembimbing khusus juga ikut berperan dalam penyusunan rencana pelaksanaan pembelajaran mata pelajaran matematika. Peran guru pembimbing khusus pada tahap perencanaan pembelajaran ini adalah memberikan masukan tentang perlakuan yang tepat untuk siswa slow learner serta menentukan soal atau asesmen penilaian hasil belajar seperti apa yang bisa diberikan untuk siswa slow learner. Hal ini sesuai dengan tugas guru pembimbing khusus yang dinyatakan dalam Pedoman Khusus Penyelenggaraan Pendidikan Inklusif tentang Pengadaan dan Pembinaan Tenaga Pendidik yang dipublikasikan oleh Direktorat Pembinaan Sekolah Luar Biasa, yaitu menyusun instrumen asesmen pendidikan bersama-sama dengan guru mata pelajaran.

\section{Pelaksanaan Pembelajaran Matema-} tika Slow Learner di Kelas Inklusif

Proses pembelajaran matematika slow learner di kelas inklusif diampu oleh seorang guru mata pelajaran matematika dan dua orang guru pembimbing khusus. Meskipun terdapat dua orang guru pembimbing khusus, pada pelaksanaannya hanya satu orang yang bertugas memberikan pendampingan terhadap siswa slow learner di ruang kelas inklusif saat pembelajaran matematika berlangsung. Guru pembimbing khusus I bertugas secara bergantian dengan guru pembimbing khusus II untuk mendampingi siswa slow learner di kelas dan senantiasa duduk di samping siswa slow learner selama pembelajaran matematika berlangsung. Pendampingan oleh guru pembimbing khusus ini dilakukan mulai dari awal hingga akhir proses pembelajaran matematika.

Pendampingan oleh guru pembimbing khusus tidak selalu terus-menerus dilakukan dalam ruang kelas reguler. Ada saat-saat tertentu pendampingan ini dilakukan di ruang yang berbeda dengan kelas reguler. Hal ini dikarenakan SMP Garuda Cendekia menerapkan model penempatan kelas reguler dengan sistem pull out pada siswa slow learner, yaitu penarikan siswa slow learner pada waktu-waktu tertentu untuk melakukan pembelajaran di luar kelas reguler (Wahyudi \& Kristiawati, 2016). Pembelajaran model pull out ini dilakukan di suatu ruang yang disebut sebagai ruang sumber dan dimaksudkan untuk melakukan pembimbingan secara lebih khusus agar siswa slow learner merasa kondusif saat belajar.

Kendati demikian, tahapan kegiatan pembelajaran matematika slow learner di kelas inklusif SMP Garuda Cendekia dilakukan sama seperti halnya pembelajaran di sekolah reguler, yaitu pendahuluan atau apersepsi, kegiatan inti, dan penutup. Kegiatan pendahuluan atau apersepsi dilakukan oleh guru mata pelajaran bersama dengan siswa reguler 
dan siswa slow learner. Pada kegiatan ini, guru mata pelajaran memberi perlakuan yang sama kepada semua siswa, termasuk siswa slow learner. Guru mata pelajaran menyampaikan informasi mengenai tujuan dan manfaat mempelajari materi pembelajaran. Tidak terdapat perbedaan kegiatan pembelajaran antara siswa reguler dengan siswa slow learner pada tahap ini. Guru pembimbing khusus pun tidak banyak berperan pada kegiatan pendahuluan ini.

Kegiatan inti juga dilakukan oleh guru mata pelajaran bersama dengan siswa reguler maupun siswa slow learner. Pada kegiatan ini, guru mata pelajaran belum pernah menerapkan pembelajaran kelompok. Guru mata pelajaran selalu menggunakan metode ekspositori, yaitu penjelasan materi secara klasikal yang disertai dengan tanya jawab. Saat penyampaian materi pembelajaran oleh guru mata pelajaran, konsentrasi dari siswa slow learner mudah teralihkan sehingga ia kurang mampu untuk memfokuskan dirinya dalam mendengar dan memperhatikan penjelasan dari guru mata pelajaran (Aziz et al., 2015). Pada kondisi seperti ini, guru pembimbing khusus berperan dalam menegur dan mengingatkan siswa slow learner untuk kembali konsentrasi memperhatikan penjelasan dari guru mata pelajaran (Yusuf et al., 2018).

Ketika guru mata pelajaran melakukan tanya jawab dengan siswa terkait dengan materi pembelajaran, maka siswa slow learner pun juga mendapat kesempatan untuk diberikan pertanyaan oleh guru mata pelajaran. Akan tetapi, guru mata pelajaran sudah menyiapkan pertanyaan yang sekiranya bisa dijawab oleh siswa slow learner. Jika siswa slow learner tidak mampu menjawab pertanyaan yang diajukan oleh guru mata pelajaran, maka pertanyaan tersebut akan dialihkan ke siswa reguler untuk menghindari perubahan emosi dari siswa slow learner.

Siswa slow learner yang menjadi subjek penelitian mempunyai gaya bahasa dalam berkomunikasi yang berbeda dari teman-teman sebayanya. Ia mempunyai kebiasaan menggunakan bahasa baku dalam berkomunikasi. Hal ini membuatnya cenderung enggan untuk bertanya kepada guru mata pelajaran pada saat pembelajaran di kelas reguler. Ia juga enggan untuk bertanya kepada teman sebayanya jika mengalami kesulitan dalam memahami materi pelajaran. Ia lebih memilih untuk bertanya kepada guru pembimbing khusus.

Kegiatan inti lainnya yang juga sering diterapkan guru mata pelajaran dalam pembelajaran matematika di kelas inklusif adalah pemberian soal latihan. Soal yang diberikan disamakan antara siswa reguler dengan siswa slow learner. Pada kegiatan ini, siswa slow learner lebih sering meminta guru pembimbing khusus untuk melakukan pull out. Hal ini dilakukan karena siswa slow learner merasa perlu diberikan penjelasan ulang mengenai materi yang telah diajarkan oleh guru mata pelajaran di kelas. Selain itu, siswa slow learner merasa lebih kondusif belajar di ruang sumber karena terhindar dari suara-suara lain yang bisa memecah konsentrasinya.

Kegiatan pull out ini sepenuhnya dibantu oleh guru pembimbing khusus 
karena pembelajaran dilakukan di luar kelas. Pada saat pull out, guru pembimbing khusus akan memberikan penjelasan berulang kepada siswa slow learner tentang materi yang sedang dipelajari. Hal ini sesuai dengan pendapat Shaw (2010) yang menyatakan bahwa slow learner membutuhkan pengulangan dalam mempelajari suatu materi karena kekurangmampuannya dalam mengaitkan konsep terdahulu dengan konsep yang baru. Pernyataan tersebut juga diperkuat oleh hasil penelitian Tran et al. (2019) yang menyatakan bahwa salah satu strategi yang tepat untuk dilakukan guru kepada siswa slow learner adalah dengan memberikan penjelasan berulang. Jika penjelasan sudah diberikan secara berulang tetapi siswa slow learner masih belum mampu memahami materi tersebut, maka guru pembimbing khusus akan menyarankan guru mata pelajaran untuk menghilangkan materi tersebut pada asesmen penilaian harian.

Begitu pula dalam pengerjaan soal latihan. Jika siswa slow learner merasa kesulitan dalam mengerjakan suatu soal karena tingkat kesulitan yang cukup tinggi, maka guru pembimbing khusus akan mengganti dengan soal lain yang sejenis tetapi dengan tingkat kesulitan yang lebih rendah. Jika soal pengganti tersebut tetap sulit untuk dipahami dan diselesaikan oleh siswa slow learner dikarenakan kekurangmampuannya dalam memahami materi pelajaran yang berkaitan dengan soal tersebut, maka guru pembimbing khusus akan menghilangkan soal dengan jenis tersebut sehingga siswa slow learner tidak lagi mengerjakan soal dengan jenis tersebut pada asesmen penilaian harian.
Perlakuan penggantian dan penghilangan pada materi pembelajaran maupun pada asesmen penilaian merupakan salah satu adaptasi kurikulum pendidikan inklusif yang disebut dengan modifikasi (Yusuf et al., 2018). Hal ini dilakukan dalam rangka memfasilitasi karakteristik, kebutuhan, dan kemampuan akademis siswa slow learner dalam setting pendidikan inklusif. Pemfasilitasian seperti ini diperkuat oleh Kaur \& Masura (2011) yang berpendapat bahwa perlakuan dalam pembelajaran yang disesuaikan dengan karakteristik slow learner akan mampu meningkatkan performa akademis dari slow learner.

Selama kegiatan pull out, menurut guru pembimbing khusus, siswa slow learner tidak menunjukkan sikap malas belajar. Siswa slow learner tidak menolak ketika diminta mengerjakan soal. Ia akan langsung mencoba untuk mengerjakan soal yang diberikan guru mata pelajaran di kelas dengan kemampuannya sendiri jika ia sudah mampu memahami materi yang diajarkan guru pembimbing khusus. Ketika ia mengalami kesulitan dalam mengerjakan soal, ia tidak akan merasa enggan untuk langsung bertanya kepada guru pembimbing khusus.

Kegiatan pull out tidak selalu dilakukan pada setiap pertemuan. Ada kalanya siswa slow learner melakukan pembelajaran matematika secara penuh di kelas reguler tetapi tetap dengan pendampingan guru pembimbing khusus. Kondisi ini terjadi ketika materi pelajaran yang diajarkan mudah dipahami oleh siswa slow learner sehingga tidak dilakukan kegiatan pull out. Adakalanya pula siswa slow learner 
melakukan pembelajaran matematika secara penuh di kelas reguler tanpa pendampingan guru pembimbing khusus pada saat guru pembimbing khusus berhalangan hadir ke sekolah. Kondisi ini menjadikan guru mata pelajaran menyamakan seluruh kegiatan inti untuk semua siswa, baik siswa reguler maupun siswa slow learner. Kondisi tersebut juga menjadikan tidak adanya penjelasan materi secara berulang bagi siswa slow learner karena guru mata pelajaran harus membagi perhatian kepada anak reguler yang jumlahnya lebih banyak daripada siswa slow learner.

Pelaksanaan pembelajaran matematika di kelas reguler ditutup dengan melakukan refleksi yang dibimbing oleh guru mata pelajaran. Pada tahap ini, jika siswa slow learner sedang melakukan pull out di ruang sumber, maka kegiatan refleksi akan dilakukan bersama guru pembimbing khusus dengan melakukan recalling sebelum membuat kesimpulan terhadap materi pembelajaran yang telah dipelajari. Akan tetapi, jika siswa slow learner melaksanakan pembelajaran matematika secara penuh tanpa pull out, maka kegiatan refleksi akan dilakukan bersama dengan guru mata pelajaran dan siswa lainnya di kelas reguler.

\section{Kegiatan Evaluasi Pembelajaran Matematika Slow Learner di Kelas Inklusif}

Kegiatan evaluasi pembelajaran matematika di kelas inklusif dilakukan sama dengan kelas reguler di sekolah umum, yaitu pemberian soal latihan, pelaksanaan penilaian harian, penilaian tengah semester, dan penilaian akhir semester. Semua instrumen soal untuk kegiatan evaluasi pembelajaran matematika tersebut disusun oleh guru mata pelajaran yang kemudian dilakukan penyesuaian terhadap kemampuan siswa slow learner oleh guru pembimbing khusus. Soal yang memiliki tingkat kesulitan yang cukup tinggi akan dihilangkan dari instrumen oleh guru pembimbing khusus dengan diketahui oleh guru mata pelajaran. Akan tetapi, modifikasi soal ini tidak diinformasikan kepada siswa slow learner dengan tujuan agar siswa slow learner tidak merasa dibedakan dengan temannya yang lain.

Namun demikian, berdasarkan hasil wawancara terhadap guru pembimbing khusus I dan II, meskipun dilakukan modifikasi soal untuk siswa slow learner, bukan berarti ia akan selalu mendapatkan nilai yang memuaskan. Siswa slow learner kesulitan untuk mencapai nilai ketuntasan minimal yang ditetapkan guru mata pelajaran, terutama pada penilaian tengah semester maupun penilaian akhir semester. Jika dikaitkan dengan teori tentang karakteristik slow learner, maka kondisi tersebut dimungkinkan karena siswa slow learner memiliki kesulitan dalam mengaitkan satu materi dengan materi lainnya, sehingga menjadikannya kurang mampu untuk meraih hasil belajar yang memuaskan (Shaw, 2010; Watson \& Rangel, 1989).

Oleh karena itu, jika siswa slow learner mendapatkan hasil belajar yang belum sesuai dengan nilai ketuntasan minimal, maka siswa slow learner akan melaksanakan kegiatan remedial, sama seperti siswa reguler lainnya. Kegiatan remedial pada siswa slow learner dilakukan pada saat yang bersamaan 
dengan kegiatan remedial bagi siswa reguler. Akan tetapi, kegiatan remedial pada siswa slow learner dilakukan di ruang sumber dengan melakukan sistem pull out, sedangkan kegiatan remedial bagi siswa reguler dilaksanakan oleh guru mata pelajaran di ruang kelas reguler. Hal ini bertujuan agar siswa slow learner mempunyai suasana yang kondusif dalam melaksanakan kegiatan remedial tersebut (Krishnakumar et al., 2011).

Pelaksanaan kegiatan remedial sepenuhnya dilakukan oleh guru pembimbing khusus dengan memberikan penjelasan ulang terhadap materi yang belum dipahami siswa slow learner. Setelah itu, siswa slow learner akan diberikan soal remedial test dalam bentuk tes tertulis. Instrumen soal disusun oleh guru mata pelajaran yang kemudian dilakukan modifikasi untuk soal yang mempunyai tingkat kesulitan cukup tinggi. Pelaksanaan kegiatan remedial oleh guru pembimbing khusus terhadap siswa slow learner tersebut sesuai dengan Pedoman Khusus Penyelenggaraan Pendidikan Inklusif tentang Pengadaan dan Pembinaan Tenaga Pendidik yang dipublikasikan oleh Direktorat Pembinaan Sekolah Luar Biasa Tahun 2007 yang menyatakan bahwa guru pembimbing khusus bertugas memberikan bantuan bagi siswa berkebutuhan khusus yang mengalami hambatan dalam proses pembelajaran di kelas inklusif berupa kegiatan remedial.

\section{PENUTUP}

Berdasarkan pengumpulan data melalui wawancara semi-terstruktur dengan guru mata pelajaran, guru pembimbing khusus I, guru pembimbing khusus II, dan kepala SMP Garuda Cendekia Jakarta, yang kemudian dilakukan validasi data serta analisis data, maka diperoleh hasil penelitian mengenai profil pembelajaran matematika anak berkebutuhan khusus ragam slow learner di kelas inklusif, yaitu: (1) kurikulum yang digunakan siswa slow learner disamakan dengan kurikulum reguler, tetapi dilakukan adaptasi kurikulum berupa modifikasi, (2) penggunaan model maupun metode pembelajaran di kelas inklusif disamakan antara siswa slow learner dengan siswa reguler tanpa penyusunan program pendidikan individual, tetapi pelaksanaannya dilakukan dengan memperhatikan karakteristik siswa slow learner, dan (3) kegiatan evaluasi dilakukan melalui tes tertulis yang disusun oleh guru mata pelajaran yang kemudian dilakukan penyesuaian oleh guru pembimbing khusus berdasarkan model modifikasi.

\section{DAFTAR PUSTAKA}

Agusta, I. (2003). Teknik pengumpulan dan analisis data kualitatif. Bogor.

Aziz, A. N., Sugiman, \& Prabowo, A. (2015). Analisis proses pembelajaran matematika pada anak berkebutuhan khusus (abk) slow learner di kelas inklusif SMP Negeri 7 Salatiga. Kreano, 6(2), 111-120. https://doi.org/https://doi.org/10.1 5294/kreano.v6i2.4168

Bachri, B. S. (2010). Meyakinkan validitas data melalui triangulasi pada penelitian kualitatif. Jurnal Teknologi Pendidikan, 10(1), 4662. 
Departemen Pendidikan Nasional. (2007). Pedoman khusus penyelenggaraan pendidikan inklusif tentang pengadaan dan pembinaan tenaga pendidik. Jakarta: Direktorat Pembinaan Sekolah Luar Biasa.

Edi, F. R. S. (2016). Teori wawancara psikodignostik. Yogyakarta: Leutikaprio.

Fajarini, U. (2014). Peranan kearifan lokal dalam pendidikan karakter. Sosio Didaktika, 1(2), 123-130.

Febriyanti, C., \& Irawan, A. (2018). Pembelajaran matematika pada siswa berkebutuhan khusus di sekolah inklusi. Journal of Medives, 2(1), 99-106. Retrieved from http://e-journal.ikipveteran.ac.id/index.php/matematik a/article/view/509

Hadi, F. R. (2016). Proses pembelajaran matematika pada anak slow learners (lamban belajar). Premiere Educandum, 6(1), 3541.

Handayani, T., \& Rahadian, A. S. (2013). Peraturan perundangan dan implementasi pendidikan inklusif. Masyarakat Indonesia, 39(1), 27-48.

Jonsen, K., \& Jehn, K. A. (2009). Using triangulation to validate themes in qualitative studies. Qualitative Research in Organizations and Management: An International Journal, 4(2), 123-150. https://doi.org/10.1108/17465640 910978391

Kaur, B., \& Masura, G. (2011). Low attainers in primary mathematics. Retrieved from https://remotelib.ui.ac.id:2151
Kaznowski, K. (2004). Slow learners: Are educators leaving them behind? National Association of Secondary School Principals. NASSP Bulletin, 88(641), 31-45. Retrieved from https://remotelib.ui.ac.id:2076/docview/216042 748 ? accountid $=17242$

Krishnakumar, P., Jisha, A. M., Sukumaran, S. K., \& Nair, M. K. C. (2011). Developing a model for resource room training for slow learners in normal schools. Indian Journal of Psychiatry, 53(4), 336339. https://doi.org/10.4103/00195545.91908

Levine, M., \& Barringer, M.-D. (2008). Brain-based research helps to identify and treat slow learners. The Education Digest, 73(9), 913. Retrieved from https://remotelib.ui.ac.id:2076/docview/218177 963 ? accountid $=17242$

Malik, N. I., Rehman, G., \& Hanif, R. (2012). Effect of academic interventions on the developmental skills of slow learners. Pakistan Journal of Psychological Research, 27(1), 135-151. Retrieved from https://remotelib.ui.ac.id:2076/docview/101996 7689 ? accountid $=17242$

Miles, M. B., \& Huberman, A. M. (1994). Qualitative data analysis. Thousand Oaks: SAGE Publications.

Pandey, S., \& Kurian, B. J. (2016). An effective way to deal with slow learners: Positive response teaching. IOSR Journal of Research \& Method in Education, 6(6), 19-22. https://doi.org/10.9790/73880606071922 
Qu, S. Q., \& Dumay, J. (2011). The qualitative research interview. Qualitative Research in Accounting \& Management, 8(3), 238-264.

https://doi.org/10.1108/11766091 111162070

Raco, J. R. (2010). Metode penelitian kualitatif: Jenis, karakteristik, dan keunggulannya. Grasindo.

Republik Indonesia. (2003). UndangUndang Republik Indonesia Nomor 20 tentang Sistem Pendidikan Nasional.

Republik Indonesia. (2009). Peraturan Menteri Pendidikan Nasional Republik Indonesia Nomor 70 tentang Pendidikan Inklusif bagi Peserta Didik yang Memiliki Kelainan dan Memiliki Potensi Kecerdasan dan/atau Bakat Istimewa.

Republik Indonesia. (2011). Peraturan Menteri Negara Pemberdayaan Perempuan dan Perlindungan Anak Republik Indonesia Nomor 10 tentang Kebijakan Penanganan Anak Berkebutuhan Khusus. Jakarta: Kementerian Pemberdayaan Perempuan dan Perlindungan Anak.

Republik Indonesia. (2014). Peraturan Menteri Pendidikan dan Kebudayaan Republik Indonesia Nomor 157 tentang Kurikulum Pendidikan Khusus.

Rohaeti, E. E., Hendriana, H., \& Sumarmo, U. (2019). Pembelajaran inovatif matematika bernuansa pendidikan nilai dan karakter. Bandung: Refika Aditama.
Shaw, S. R. (2008). An educational programming framework for a subset of students with diverse learning needs: Borderline intellectual functioning. Intervention in School and Clinic, 43(5), 291-299. Retrieved from https://remotelib.ui.ac.id:2076/docview/211731 517 ? accountid $=17242$

Shaw, S. R. (2010, February). Rescuing students from the slow learner trap. Principal Leadership. National Association of School Psychologists (NASP), 12-16. Retrieved from www.nasponline.org/resources/pri ncipals

Tran, T., Tuyen, T. T. N., Trinh, T. T. Le, \& Tai, A. P. (2019). Slow learners in mathematics classes: the experience of Vietnamese primary education. Education 3-13, O(0), $1-17$.

https://doi.org/10.1080/03004279. 2019.1633375

Verbeke, K. A. (2002). Identifying accommodations for inclusion settings : A strategy for special and general educators. Electronic Journal for Inclusive Education, 1(6). Retrieved from https://corescholar.libraries.wright .edu/cgi/viewcontent.cgi?article $=1$ $038 \&$ context $=$ ejie

Wahyudi, \& Kristiawati, R. (2016). Gambaran sekolah inklusif di Indonesia (Tinjauan sekolah menengah pertama). Jakarta: Pusat Data dan Statistik Pendidikan dan Kebudayaan Kementerian Pendidikan dan Kebudayaan.

Watson, D. L., \& Rangel, L. (1989). Don't forget the slow learner. The Clearing House, 62(6), 266-268. 
Winarsih, S., Jamal's, H., Asiah, A., Idris, F. H., Adnan, E., Prasojo, B., ... Sembada, I. K. (2013). Panduan penanganan anak berkebutuhan khusus bagi pendamping (orang tua, keluarga, dan masyarakat). Jakarta.

Yusuf, M., Kustawan, D., Sumpena, A., Nugroho, B., Pristiwaluyo, T., Rakhman, A. A., ... Budiyanto. (2018). Bahan ajar bimbingan teknis pembelajaran anak berkebutuhan khusus (abk) bagi guru SMA-SMK penyelenggara pendidikan inklusif. Jakarta: Kementerian Pendidikan dan Kebudayaan Direktorat Jenderal Guru dan Tenaga Kependidikan Direktorat Pembinaan Guru Pendidikan Menengah. 